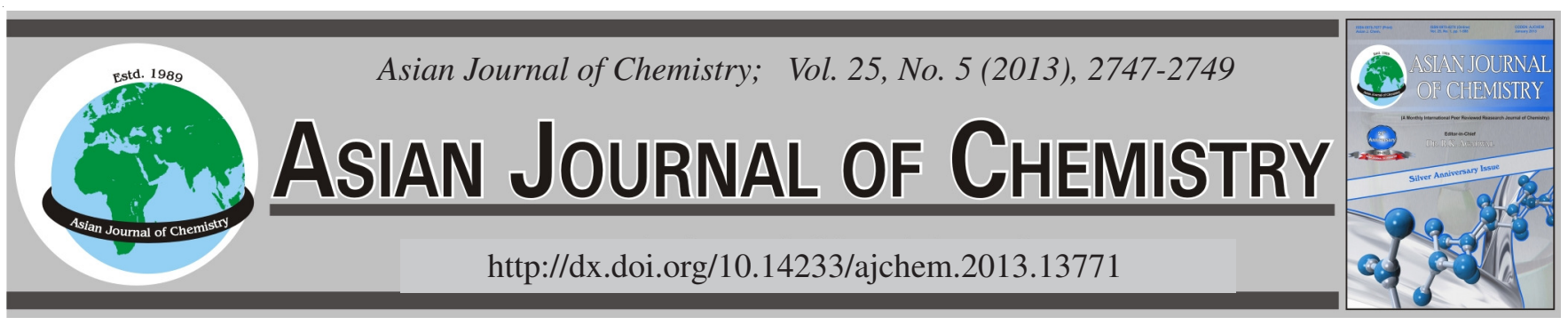

\title{
Phenolic Compounds from Arundina graminifolia and Their Anti-Tobacco Mosaic Virus Activities
}

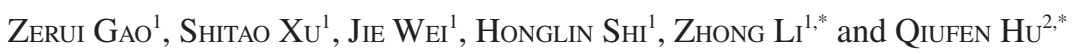

${ }^{1}$ Key Laboratory of Tobacco Chemistry of Yunnan Province, Yunnan Academy of Tobacco Science, Kunming 650106, P.R. China ${ }^{2}$ Key Laboratory of Ethnic Medicine Resource Chemistry (Yunnan University of Nationalities), State Ethnic Affairs Commission and Ministry of Education, Kunming 650031, P.R. China

*Corresponding author: E-mail: ycslizhong@163.com; huqiufena@yahoo.com.cn

\begin{abstract}
A new phenolic compounds, gramphenol A, together with three known phenols (2-4), were isolated from the whole plant of Arundina gramnifolia. The structure of compounds 1-4 was elucidated by spectroscopic methods including extensive ${ }^{1} \mathrm{D}$ and ${ }^{2} \mathrm{D}$ NMR techniques. The anti-tobacco mosaic virus (anti-TMV) activities were evaluated for compounds 1-4. The results reveal that compound 1 exhibits modest anti-tobacco mosaic virus activities.
\end{abstract}

Key Words: Arundina gramnifolia, Phenolic compounds, Anti-tobacco mosaic virus activity.

\section{INTRODUCTION}

Arundina gramnifolia belongs to Orchidaceae genus. It is a terrestrial plant extends from India, Nepal, Thailand, Malaysia, Singapore, South China to Indonesia and across the Pacific Islands. The genus is considered to possess activities of detoxification, antiarthritis and abirritation and is used as antidote and demulcent ${ }^{1}$. In recent years, several papers have described phytochemistry investigations of A. gramnifolia and was found to be rich in stilbenoids and triterpenes ${ }^{2-5}$. Motivated by a search for bioactive compounds from this plant, further chemical investigation were carried out. As a result, a new phenolic compounds (1), together with three known phenols (2-4), were isolated from this plant. In addition, the antitobacco mosaic virus activities of compounds $\mathbf{1 - 4}$ were evaluated. This article deals with the isolation, structural elucidation and biological activities of the isolated compounds.

\section{EXPERIMENTAL}

Optical rotations were measured with a Horiba SEPA300 polarimeter. UV spectra were obtained using a Shimadzu UV-2401A spectrophotometer. A Tenor 27 spectrophotometer was used for scanning IR spectroscopy with $\mathrm{KBr}$ pellets. ${ }^{1} \mathrm{D}$ and ${ }^{2} \mathrm{D}$ NMR spectra were recorded on DRX-500 spectrometers with TMS as internal standard. Unless otherwise specified, chemical shifts $(\delta)$ were expressed in $\mathrm{ppm}$ with reference to the solvent signals. HRESIMS was performed on an API QSTAR time-of-flight spectrometer and a VG autospec-3000 spectrometer, respectively. Preparative HPLC was performed on a Shimadzu LC-8A preparative liquid chromatograph with a ZORBAX PrepHT GF $(21.2 \mathrm{~mm} \times 25 \mathrm{~cm}, 7 \mathrm{~mm})$ column or a Venusil MP $\mathrm{C}_{18}(20 \mathrm{~mm} \times 25 \mathrm{~cm}, 5 \mathrm{~mm})$ column. Column chromatography was performed with Si gel (200-300 mesh, Qing-dao Marine Chemical, Inc., Qingdao, China), Lichroprep RP-18 gel (40-63 $\mu \mathrm{m}$, Merck, Darmstadt, Germany) and MCI gel (75-150 $\mu \mathrm{m}$, Mitsubishi Chemical Corporation, Tokyo, Japan). The fractions were monitored by TLC and spots were visualized by heating $\mathrm{Si}$ gel plates sprayed with $5 \% \mathrm{H}_{2} \mathrm{SO}_{4}$ in EtOH.

The whole plant of A. gramnifolia was collected in Dehong prefecture of Yunnan Province, People's Republic of China, in September 2010. The identification of plant material was verified by Prof. Ning Yuan. A voucher specimen (Ynni-1009-28) has been deposited in our Laboratory.

Extraction and isolation: The air-dried and powdered of whole plant of A. gramnifolia (2 $\mathrm{kg}$ ) were extracted three times with $70 \%$ aqueous $\mathrm{MeOH}(3 \times 3.5 \mathrm{~L})$ at room temperature and filtered to yield a filtrate, which was successively evaporated under reduced pressure to obtained a crude extract (115 g). This crude extract was applied to Si gel (200-300 mesh) column chromatography eluting with a $\mathrm{CHCl}_{3}-\mathrm{MeOH}$ gradient system $(20: 1,9: 1,8: 2,7: 3,6: 4,5: 5)$ to give six fractions A-F. The separation of fraction A (11.8 g) by Si gel column chromatography eluted with $\mathrm{CHCl}_{3}$-acetone (1:0-1:2) yielded mixtures A1-A6. Fraction A1 (pure $\mathrm{CHCl}_{3}, 3.89$ g) was subjected to Si gel column chromatography using petroleum ether-acetone and preparative $\mathrm{HPLC}\left(80 \% \mathrm{MeOH}-\mathrm{H}_{2} \mathrm{O}\right.$, flow rate $12 \mathrm{~mL} / \mathrm{min}$ ) to give compounds $\mathbf{1}(19.2 \mathrm{mg})$. Fraction 
$\mathrm{A}_{3}(8: 2,3.86 \mathrm{~g})$ was subjected to $\mathrm{Si}$ gel column chromatography eluting with petroleum ether-acetone and then run on preparative $\mathrm{HPLC}\left(65 \% \mathrm{MeOH}-\mathrm{H}_{2} \mathrm{O}\right.$, flow rate $12 \mathrm{~mL} / \mathrm{min}$ ) to yield compounds $4(63.6 \mathrm{mg})$. The separation of fraction B $(18.5 \mathrm{~g})$ by $\mathrm{Si}$ gel column chromatography eluted with $\mathrm{CHCl}_{3}$-acetone (9:1-1:2) yielded mixtures B1-B6. Fraction B2 (7:3, $3.89 \mathrm{~g})$ was subjected to $\mathrm{Si}$ gel column chromatography using petroleum ether-acetone and preparative $\mathrm{HPLC}\left(50 \% \mathrm{MeOH}-\mathrm{H}_{2} \mathrm{O}\right.$, flow rate $12 \mathrm{~mL} / \mathrm{min}$ ) to give compound $\mathbf{3}(19.2 \mathrm{mg})$. Fraction B3 $(6: 4,3.86 \mathrm{~g})$ was subjected to Si gel column chromatography eluting with petroleum ether-acetone and then run on preparative HPLC (45\% MeOH- $\mathrm{H}_{2} \mathrm{O}$, flow rate $12 \mathrm{~mL} / \mathrm{min}$ ) to yield compounds 2 (28.8 mg).

Anti-tobacco mosaic virus assays: The anti-tobacco mosaic virus activity was tested using the half-leaf method ${ }^{12}$. The inhibitory activities of the compounds against tobacco mosaic virus replication were tested using two approaches. First, the half-leaf method was used to test the antiviral activity in the local lesion host $N$. glutinosa in vivo. Then, the leafdisk method was used to evaluate the antiviral activity of the compounds in the systemic infection host $N$. tabacum cv. K326. Ningnanmycin $(20 \mu \mathrm{M})$, a commercial product for plant disease in China, was used as a positive control.

Gramniphenol A (1): Obtain as brown oil; UV (MeOH) $\lambda_{\text {max }}(\log \varepsilon): 210$ (4.36), 282 (3.75), 340 (2.76) nm; IR (KBr, $\left.v_{\max }, \mathrm{cm}^{-1}\right): 3452,2968,2920,2885,1623,1448,1375,1358$, 1172, 1065. Positive ESIMS m/z $365[\mathrm{M}+\mathrm{Na}]^{+}$; HRESIMS: $m / z 365.2450[\mathrm{M}+\mathrm{Na}]^{+}$, (calcd. $\mathrm{C}_{23} \mathrm{H}_{34} \mathrm{O}_{2} \mathrm{Na}$ for 365.2457).

\section{RESULTS AND DISCUSSION}

The air-dried and powdered whole plant of A. gramnifolia $(2.0 \mathrm{~kg})$ was extracted with $70 \%$ aqueous methanol $(3 \times 3.5 \mathrm{~L})$ at room temperature and filtered to yield a filtrate, which was successively evaporated under reduced pressure to obtained a crude extract (115 g). This crude extract was subjected repeatedly to column chromatography on Si gel, Sephadex LH-20, RP-18 and preparative HPLC to afford compounds 1-4 (Fig. 1), including a new phenolic compound, gramphenol $\mathrm{A}(\mathbf{1})$, together with three known phenols, cucapitoside $(\mathbf{2})^{6}$, curcapital $(\mathbf{3})^{7},(+)$-licarin A $(\mathbf{4})^{8}$. The structures of the compounds 1-4 were as shown in Fig. 1 and the NMR data of 1 were listed in Table-1.<smiles>COc1cc(I)c(CC=C(C)CCC=C(C)C)c(O)c1[CH]C=C(C)C</smiles>

1<smiles>OC[C@H]1C[C@H]2O[C@@H]3CC4c5cc(O)c(O)cc5-c5cc(O)c(O)cc5C4O[C@H]3O[C@H]2[C@H](O)[C@@H]1O</smiles>

2

Fig. 1. Structure of compounds $\mathbf{1 - 4}$

\begin{tabular}{|c|c|c|}
\hline \multicolumn{3}{|c|}{ 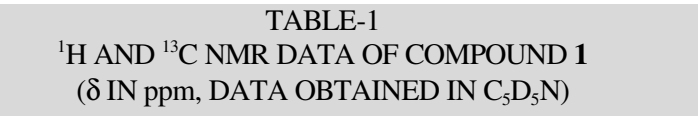 } \\
\hline No. & $\delta_{\mathrm{C}}$ (mult) & $\delta_{\mathrm{H}}($ mult, $\mathrm{J}, \mathrm{Hz}$ ) \\
\hline 1 & $155.6 \mathrm{~s}$ & \\
\hline 2 & $110.3 \mathrm{~s}$ & \\
\hline 3 & $152.8 \mathrm{~s}$ & \\
\hline 4 & $118.6 \mathrm{~s}$ & \\
\hline 5 & $135.8 \mathrm{~s}$ & \\
\hline 6 & $107.2 \mathrm{~d}$ & $6.31 \mathrm{~s}$ \\
\hline 7 & $19.8 \mathrm{q}$ & $2.23 \mathrm{~s}$ \\
\hline $1^{\prime}$ & $25.4 \mathrm{t}$ & $3.26, \mathrm{~d}, J=6.6$ \\
\hline $2^{\prime}$ & $122.0 \mathrm{~d}$ & $5.15 \mathrm{t}, J=6.7$ \\
\hline $3^{\prime}$ & $137.2 \mathrm{~s}$ & \\
\hline $4^{\prime}$ & $39.1 \mathrm{t}$ & $2.02 \mathrm{~m}$ \\
\hline $5^{\prime}$ & $26.0 \mathrm{t}$ & $2.11 \mathrm{~m}$ \\
\hline $6^{\prime}$ & $123.5 \mathrm{~d}$ & $5.52 \mathrm{~m}$ \\
\hline $7^{\prime}$ & $131.3 \mathrm{~s}$ & \\
\hline $8^{\prime}$ & $25.2 \mathrm{q}$ & $1.64 \mathrm{~s}$ \\
\hline $9^{\prime}$ & $15.8 \mathrm{q}$ & $1.77, \mathrm{~d}, J=1.1$ \\
\hline $10^{\prime}$ & $17.4 \mathrm{q}$ & $1.57 \mathrm{~s}$ \\
\hline $1^{\prime \prime}$ & $22.3 \mathrm{t}$ & $3.35, \mathrm{~d}, J=7.0$ \\
\hline $2^{\prime \prime}$ & $123.8 \mathrm{~d}$ & $5.21, \mathrm{t}, J=7.1$ \\
\hline $3^{\prime \prime}$ & $134.1 \mathrm{~s}$ & \\
\hline $4^{\prime \prime}$ & $17.1 \mathrm{q}$ & $1.79 \mathrm{~s}$ \\
\hline $5^{\prime \prime}$ & $25.0 \mathrm{q}$ & $1.72, \mathrm{~s}$, \\
\hline$-\mathrm{OMe}$ & $55.8 \mathrm{q}$ & $3.87 \mathrm{~s}$ \\
\hline $\mathrm{Ar}-\mathrm{OH}$ & & $11.2 \mathrm{~s}$ \\
\hline
\end{tabular}

Compound 1 was isolated as a brown oil with the molecular formula $\mathrm{C}_{23} \mathrm{H}_{36} \mathrm{O}_{2}$ as indicated by the quasi-molecular ion at $m / z, 365.2450[\mathrm{M}+\mathrm{Na}]^{+}$in its HRESIMS. Its IR spectrum showed absorption bands at 3452, 2968-2855, 1623 and 1448 $\mathrm{cm}^{-1}$ indicative of hydroxyl, methine, methylene, methyl and aromatic groups, respectively. The ${ }^{1} \mathrm{H}$ NMR displayed two signals at $\delta_{\mathrm{H}} 6.31$ (s) and $2.23(\mathrm{~s})$ assigned to aromatic hydrogen and to an aromatic methyl group, respectively. The spectrum also showed a set of characteristic signals of a prenyl group: two hydrogen at $\delta_{\mathrm{H}} 3.26(\mathrm{~d}, J=6.6 \mathrm{~Hz})$ coupled with hydrogen at $\delta_{\mathrm{H}} 5.15(\mathrm{t}, J=6.7 \mathrm{~Hz})$ and additionally, two methyl groups at $\delta_{\mathrm{H}} 1.79$ and $1.72(\mathrm{~s})$. A second set of signals was observed in this spectrum: two hydrogens at $\delta_{\mathrm{H}} 3.35(\delta, J=7.0 \mathrm{~Hz})$ coupled with hydrogen at $\delta_{\mathrm{H}} 5.21(\mathrm{t}, J=7.1 \mathrm{~Hz})$, in addition to two multiplets at $\delta_{\mathrm{H}} 2.02$ and $2.11(2 \mathrm{H}$ each) and three methyl groups at $\delta_{\mathrm{H}} 1.77,1.57$ and $1.64(\mathrm{~s})$, characteristic of a geranyl group, was also observed. The assignment of the prenyl and geranyl groups was supported either by coupling constants or by $\mathrm{HMBC}$ data and the ${ }^{1} \mathrm{H}$ NMR data as a whole indicated that $\mathbf{1}$ has a similar structure to that of arifoliaphenol ${ }^{9}$. The obvious chemical shift differences resulted from the substituent group variations in the aromatic rings, an aromatic hydroxyl group in arifoliaphenol was substituted by a methoxyl group in 1. In order to clarify this aspect, the HMBC experiment was carried out and the correlations observed from $\mathrm{H}-1^{\prime}$ to $\mathrm{C}$ 3, $\mathrm{C}-4$ and $\mathrm{C}-2$ ', from $\mathrm{H}-1^{\prime \prime}$ to $\mathrm{C}-2, \mathrm{C}-3, \mathrm{C}-2$ " and $\mathrm{C}-3^{\prime \prime}$ and from $\mathrm{H}-7$ to $\mathrm{C}-4, \mathrm{C}-5$ and C-6 allowed the placement of methyl, prenyl and geranyl groups at C-5, C-2 and C-4, respectively (Fig. 2). Additional correlations from $\mathrm{H}-6$ to $\mathrm{C}-1, \mathrm{C}-2, \mathrm{C}-4$ and $\mathrm{C}-7$, from $\mathrm{Ar}-\mathrm{OH}$ to $\mathrm{C}-2, \mathrm{C}-3, \mathrm{C}-4$ and from-OMe to $\mathrm{C}-1$ supported the placement of the aromatic hydrogen at $\mathrm{C}-3$ and 
of the -OMe at C-1. Further confirmation for this substitution pattern on the aromatic ring was made using the NOESY experiment (Fig. 3). The compound $\mathbf{1}$ was thus deduced as show and given the name as gramphenol A.

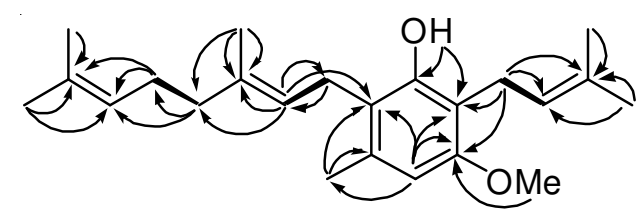

Fig. 2. Selected HMBC ( $ح$ ) correlations of compound $\mathbf{1}$

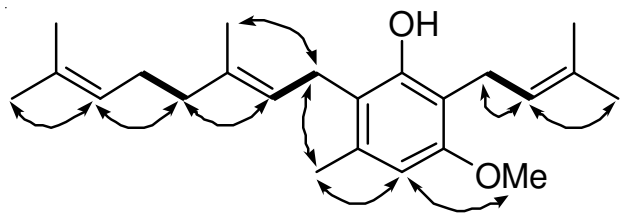

Fig. 3. Key ROESY ( ) correlations of $\mathbf{1}$

Since some of the phenolic compounds exhibited anti virus activities ${ }^{10,11}$ compounds $\mathbf{1 - 4}$ were tested for the antitobacco mosaic virus activity using the half-leaf method according to literature ${ }^{12}$.

In anti-tobacco mosaic virus activity test, the antiviral inhibition rates of the compounds at the concentration of $20 \mu \mathrm{M}$ were tested by the half-leaf method. Ningnanmycin $(20 \mu \mathrm{M})$, a commercial product for plant disease in China with inhibition rate of $33 \%$ was used as positive control. The results showed that compounds 1-4 exhibit inhibition rates of 32.8,
5.26, 16.7 and $14.8 \%$, respectively. Compounds 1 exhibited high anti-tobacco mosaic virus activity; its inhibition rate is close to that of positive control. Compounds 2-4 also exhibited weak anti-tobacco mosaic virus activity.

\section{ACKNOWLEDGEMENTS}

This project was supported financially by the Excellent Scientific and Technological Team of Yunnan High School (2010CI08) and Open Research Fund Program of Key Laboratory of Ethnic Medicine Resource Chemistry (Yunnan University of Nationalities) (2010XY08).

\section{REFERENCES}

1. D.Y. Hong, Y.S. Lian and L.D. Shen, Flora of China, Science Press, Beijing, Vol. 73, p. 320 (1983).

2. P.L. Majumder and S. Ghosal, Phytochemistry, 35, 205 (1994).

3. P.L. Majumder and S. Ghosal, Phytochemistry, 32, 439 (1993).

4. P.L. Majumder and S. Ghosal, J. Indian Chem. Soc., 68, 88 (1991).

5. M.F. Liu, Y. Han, D.M. Xing, Y. Shi, L.Z. Xu, L.J. Du and Y. Ding, J. Asian Nat. Prod. Res., 6, 229 (2004).

6. S.S. Lee, W.L. Chang and C.H. Chen, Tetrahedron Lett., 37, 4405 (1996).

7. W.L. Chang, C.H. Chen and S.S. Lee, J. Nat. Prod., 62, 734 (1999).

8. I.R. Nascimento and L.M.X. Lopes, Phytochemistry, 52, 345 (1999).

9. J.M.S. Karina, H.G.L. Joao, F.G. Elsie and J.K. Massuo, J. Braz. Chem. Soc., 23, 311 (2012).

10. X.M. Gao, H.X. Mu, X.S. Li, G.Y. Yang, G.P. Li and Q.F. Hu, J. Chin. Chem. Soc., 59, 1 (2011).

11. D. Chattopadhyay, M.C. Sarkar, T. Chatterjee, D.R. Sharma, P. Bag, S. Chakraborti and M.T.H. Khan, New. Biotech., 25, 347 (2009).

12. X.H. Yan, J. Chen, Y.T. Di, X. Fang, J.H. Dong, P. Sang, Y.H. Wang, H.P. He, Z.K. Zhang and X.J. Hao, J. Agric. Food Chem., 58, 1572 (2010). 